
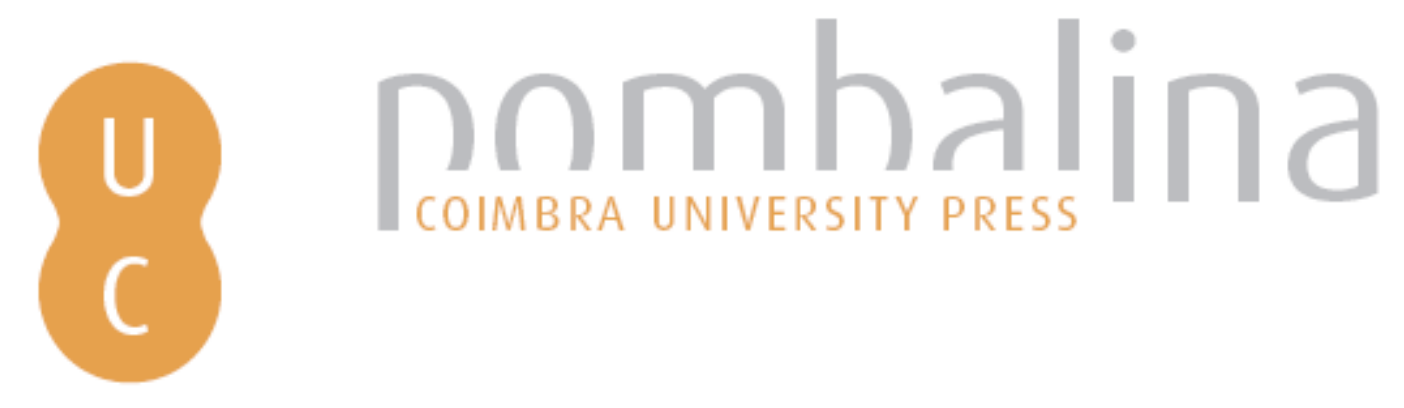

\title{
Application of energy dispersive X-ray fluoresce spectrometry (EDX ) in medico-legal autopsy case
}

\author{
Takahashi, M.; Kinoshita, H.; Kuse, A.; Morichika, M.; Nishiguchi, M.; \\ Ouchi, H.; Minami, T.; Matsui, K.; Yamamura, T.; Motomura, H.; Ohtsu, \\ N.; Yoshida, S.; Adachi, N.; Hishida, S.; Ueno, Y.; Nishio, H. \\ Publicado por: Imprensa da Universidade de Coimbra; International Academy of Legal \\ URL \\ persistente: \\ URI:http://hdl.handle.net/10316.2/31854 \\ DOI: DOI:http://dx.doi.org/10.14195/978-989-26-0173-1_55 \\ Accessed : $\quad$ 26-Apr-2023 11:29:26
}

A navegação consulta e descarregamento dos títulos inseridos nas Bibliotecas Digitais UC Digitalis, UC Pombalina e UC Impactum, pressupõem a aceitação plena e sem reservas dos Termos e Condições de Uso destas Bibliotecas Digitais, disponíveis em https://digitalis.uc.pt/pt-pt/termos.

Conforme exposto nos referidos Termos e Condições de Uso, o descarregamento de títulos de acesso restrito requer uma licença válida de autorização devendo o utilizador aceder ao(s) documento(s) a partir de um endereço de IP da instituição detentora da supramencionada licença.

Ao utilizador é apenas permitido o descarregamento para uso pessoal, pelo que o emprego do(s) título(s) descarregado(s) para outro fim, designadamente comercial, carece de autorização do respetivo autor ou editor da obra.

Na medida em que todas as obras da UC Digitalis se encontram protegidas pelo Código do Direito de Autor e Direitos Conexos e demais legislação aplicável, toda a cópia, parcial ou total, deste documento, nos casos em que é legalmente admitida, deverá conter ou fazer-se acompanhar por este aviso.

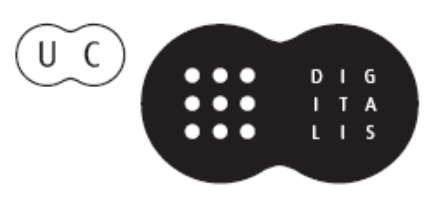




\section{Duarte Nuno Vieira Anthony Busuttil \\ Denis Cusack • Philip Beth}
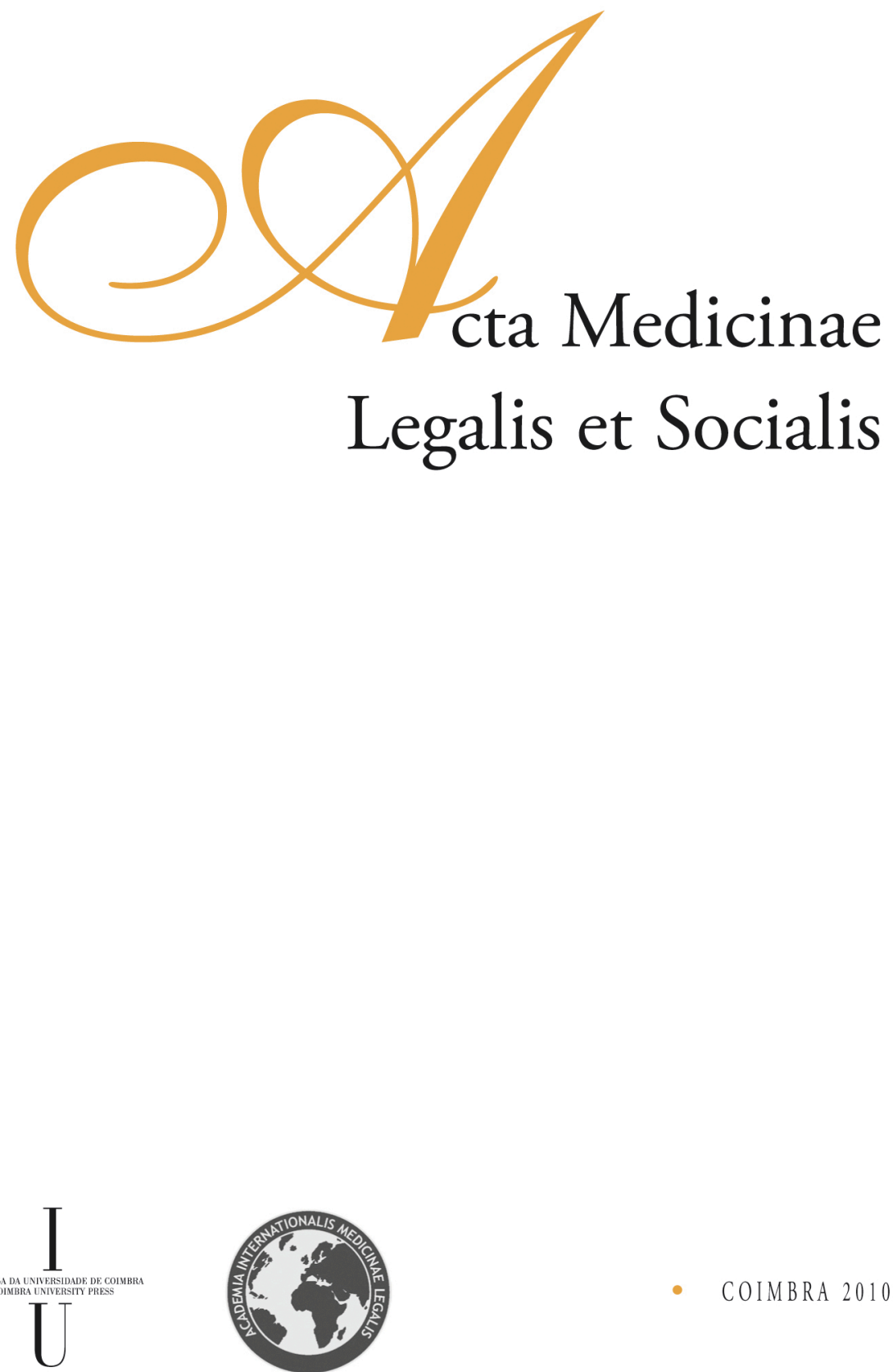
M. Takahashi ${ }^{1}$, H. Kinoshita ${ }^{1,2}$, A. Kuse ${ }^{3}$, M. Morichika ${ }^{3}$, M. Nishiguchi ${ }^{1}$, H. Ouchi ${ }^{1}$, T. Minami ${ }^{1}$, K. Matsui ${ }^{1}$, T. Yamamura ${ }^{1}$, H. Motomura ${ }^{4}$, N. Ohtsu ${ }^{1}$,

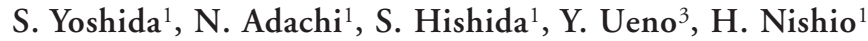

${ }^{1}$ Department of Legal Medicine, Hyogo College of Medicine, Japan

${ }^{2}$ Department of Forensic Medicine, Faculty of Medicine, Kagawa University, Japan

${ }^{3}$ Division of Legal Medicine, Department of Environmental Health and Safety, Kobe University Graduate School of Medicine, Japan

${ }^{4}$ Forensic Science Laboratory, Hyogo Prefectural Police Headquarters, Japan

\begin{abstract}
APPLICATION OF ENERGY DISPERSIVE X-RAY FLUORESCE SPECTROMETRY (EDX) IN MEDICO-LEGAL AUTOPSY CASE
\end{abstract}

\begin{abstract}
We applied here energy dispersive X-ray fluorescence spectrometry (EDX) to medicolegal autopsy case of drowning in a river under the influence of hypnotics. Rapid elemental analysis using EDX identified bromide in blood, urine and cerebrospinal fluid of victim during autopsy. Subsequent toxicological analysis with a high performance liquid chromatography revealed bromovalerylurea in blood and other specimens. Present case shows that screening using EDX, ideal examination for non-destructive, rapid elemental analysis, provides useful information for identification of drugs.
\end{abstract}

\title{
Introduction
}

Rapid screening for drug overdose and the estimation of toxic substances are important in the fields of both emergency medicine and forensic toxicology. Such screening is usually performed using an immunological screening kit or color test paper [1].

Energy dispersive X-ray fluorescence spectrometry (EDX) is an easy and convenient way to identify various elements without special sample preparation [2]. Therefore, EDX is a quite useful tool for the primary identification of toxic compounds or pharmaceutical drugs including those such as arsenic and bromine.

We previously reported EDX was useful for screening of drugs in medico-legal autopsy cases [3]. Here, we report toxicological screening by EDX in another case of bromovalerylurea ingestion which was not revealed by police investigations.

\section{Case history}

A male in his thirties (height $188 \mathrm{~cm}$, weight $115 \mathrm{~kg}$ ) was found dead in the river below the bridge. He had told to his families about his attempt of suicide. Police investigation revealed that he was suffered from depression but the medications were unclear other than diphenhydramine, commercially available as over-the-counter hypnotics in Japan. The postmortem interval was estimated to be approximately 12 hours. 
At autopsy, the lungs (left $550 \mathrm{~g}$ and right $370 \mathrm{~g}$ in weight) were edematous with marginal emphysema. White frothy fluid was found in the trachea and both bronchi. There was $500 \mathrm{ml}$ of light-brownish stomach contents, and $4 \mathrm{ml}$ of brownish liquid in sphenoidal sinus. Diatom test of lung, liver, kidney and sphenoidal sinus fluid were positive.

A drug screening test of the urine with Triage ${ }^{\circledR}$ (Biosite Diagnostic Inc., CA, USA) panel was positive for barbiturates.

\section{Materials and Methods}

The elemental screening tests and the quantification of bromide in blood, urine and cerebrospinal fluid were operated using EDX (JSX3200, JEOL, Tokyo, Japan) $[3,4]$. The quantification limit for bromide ion using this method was $19.7 \mu \mathrm{g} / \mathrm{ml}$.

Toxicological analysis was also performed using a high performance liquid chromatography (HPLC) drug analysis system (Class-VP system, Shimadzu, Kyoto, Japan) [5]. Quantification of ethanol was performed using a head-space gaschromatography.

\section{Results}

EDX spectra of blood, urine and cerebrospinal fluid from victim showed the characteristic lines of bromide (Fig. 1). From the calibration curve, the concentrations of bromide in heart blood, urine and cerebrospinal fluid were calculated as 108.1, 41.2 and $38.0 \mu \mathrm{g} / \mathrm{ml}$, respectively. Bromide was not detected from the river water using EDX, consistent with our previous report [4].

Subsequent toxicological analysis using HPLC identified bromovalerylurea, barbital and diphenhydramine within the concentrations of toxic levels (Table 1). Concentrations of ethanol in femoral blood and urine were revealed to be 0.08 and $0.22 \mathrm{mg} / \mathrm{ml}$, respectively.

\section{Discussion}

From the autopsy findings and the results of diatom test, we determined the cause of death was aspiration of river water under the influence of sedative drugs, including bromovalerylurea.

Bromide concentration in blood from normal healthy subject was reported to be approximately $5.35 \mu \mathrm{g} / \mathrm{ml}$ [6]. We previously suggested that detection of bromide in blood using EDX could be an indicator in cases of drowning in seawater [4]. In present case, bromide was detected from each specimen regardless of freshwater-drowning. These data suggested that he took some chemicals containing bromide before his death. Bromovalerylurea, bromide-containing hypnotics, was identified by the subsequent detailed toxicological examinations using HPLC. 
The concentrations of bromide in each specimen detected using EDX were different from those of bromovalerylurea by HPLC, especially in blood and urine. This may be because EDX can detect whole bromide including parent drug and its metabolites, while HPLC can detect only parent drug. Consistent with present case, Maguchi [7] also reported that blood concentration of bromide was higher than that of bromovalerylurea by 6 to 36 times.

It is reported the transfer of bromide ion into cerebrospinal fluid from blood is rarely occurred, whereas, bromovalerylurea easily invades into cerebrospinal fluid without being metabolized to bromide ion in this space [8]. Consistent with this report, in present case the concentration of bromide was more close to that of bromovalerylurea in cerebrospinal fluid than in blood.

EDX has been applied for the detection of some pharmaceuticals or metallic substances in medical fields [3, 9-11]. EDX enables non-destructive, non-degenerative analysis and is useful as a screening test when sample preservation is required for evidence.

\section{Conclusions}

We found EDX was useful as primary analysis of drug screening. Further applications in the field of forensic practice can be expected.

\section{References}

[1] Uges DRA. Hospital Toxicology. In: Moffat AC, Osselton MD, Widdop B, editors. Clarke's analysis of drugs and poisons in pharmaceuticals, body fluids and postmortem material; third edition, London, Pharmaceutical Press, 2004, pp. 3-36.

[2] Sky-Peck HH, Joseph BJ. Determination of trace elements in human serum by energy dispersive X-ray fluorescence, Clin Biochem, 14, 126-131, 1981.

[3] Takahashi M, Kinoshita H, Nishiguchi M, Kasuda S, Ouchi H, Minami T, Matsui K, Yamamura T, Motomura H, Ohta T, Komeda M, Ohtsu N, Yoshida S, Adachi N, Hishida S. Application of energy dispersive X-ray fluorescent spectrometry (EDXRF) in drug-related cases, Legal Med, 11, S411-S412, 2009.

[4] Takahashi M, Kinoshita H, Nishiguchi M, Ouchi H, Minami T, Matsui K, Yamamura T, Motomura H, Ohtsu N, Yoshida S, Adachi N, Hishida S. Application of energy dispersive $\mathrm{X}$-ray fluorescent spectrometry (EDXRF) for the quantification of bromide in water, Current study of environmental and medical sciences, 1, 11-13, 2008.

[5] Kinoshita H, Taniguchi T, Kubota A, Nishiguchi M, Ouchi H, Minami T, Utsumi T, Motomura H, Nagasaki Y, Ameno K, Hishida S. An autopsy case of imipramine poisoning, Am J Forensic Med Pathol, 26, 271-274, 2005.

[6] S. Abuku, S. Tanaka, Y. Seki, S. Imamiya, Determination of bromide ions in total blood, plasma and urine by ion chromatography with amperometric detection, Japanese Journal of Hygiene, 44, 945-952, 1989. (Article in Japanese)

[7] Maguchi K. An experimental and clinical study on the concentration of bromides in body fluid in acute intoxication by bromvalerylurea sleeping agent. Hokkaido igaku zasshi, 36, 559-567, 1961. 
[8] Naito H. Poisoning of industrial products, gases, pesticides, drugs, and natural toxins -cases, pathogenesis and its treatment- second edition, Nankodo, Tokyo, 2001.

[9] Winstanley R, Patel I, Fischer E. The determination of toxic metals in simulated stomach contents by energy dispersive X-ray fluorescence analysis and a fatal case of mercury poisoning, Forensic Sci Int, 35, 181-187, 1987.

[10] Tanaka H, Nakajima M, Fujisawa M, Kasamaki M, Hori Y, Yoshikawa H, Kitagawa S. Rapid determination of total bromide in human serum using an energy-dispersive X-ray spectrometer, Biol Pharm Bull, 26, 457-461, 2003.

[11] Kinoshita H, Nishiguchi M, Kasuda S, Matsui K, Ouchi H, Minami T, Hitate D, Ohtsu N, Yoshida S, Adachi N, Ameno K, Hishida S. Application of energy dispersive X-ray fluorescent spectrometry (EDXRF) in the field of forensic medicine: Identification of the lethal weapon, Med Biol, 152, 108-111, 2008.

[12] Winek CL, Wahba WW, Winek CL Jr, Balzer TW. Drug and chemical blood-level data 2001, Forensic Sci Int, 122, 107-123, 2001.

[13] Hishida S. Studies on the separation and quantitative determination of hypnotics by gas chromatography in forensic toxicology, Nihon Hoigaku Zasshi, 22, 577-617, 1968.

\begin{tabular}{lcccc}
\hline & Barbital & Diphenhydramine & Bromovalerylurea & bromide \\
\hline Heart blood & 17.7 & 0.9 & 9.6 & 108.1 \\
\hline Femoral blood & 16.9 & 0.9 & 9.1 & 118.6 \\
\hline Urine & 62.1 & 5.2 & Not detected & 41.2 \\
\hline cerebrospinal fluid & 15.0 & 0.4 & 5.2 & 38.0 \\
\hline Therapeutic levels in blood & $10-26$ & $0.03-0.11$ & $10-20$ & less than 500 \\
\hline Fatal levels in blood & more than 100 & more than 8 & $44-93$ & more than 3000 \\
\hline Reference & {$[12]$} & {$[12]$} & {$[13]$} & {$[10]$} \\
\hline
\end{tabular}

Table 1 - Concentrations of drugs and bromide in each specimen $(\mu \mathrm{g} / \mathrm{ml})$ with their fatal and therapeutic levels.
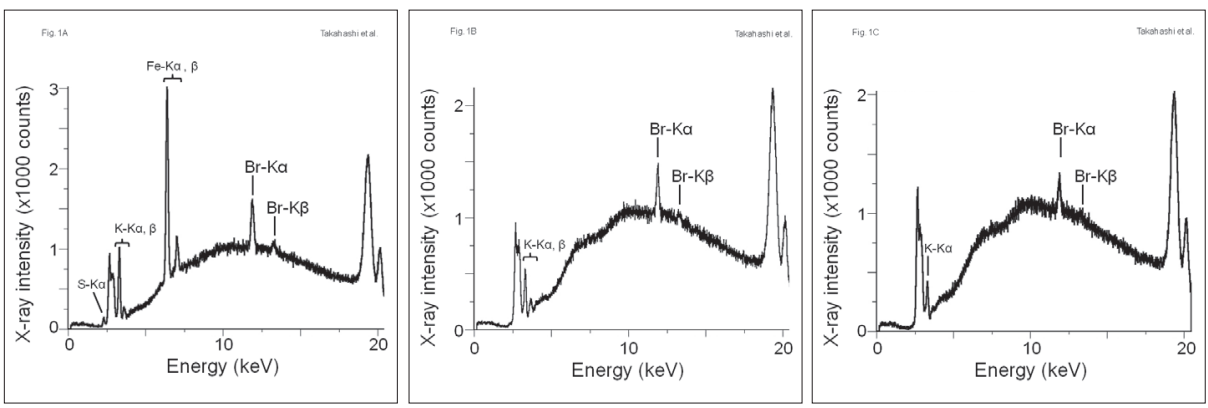

Figure 1 - EDX spectra of each sample.

The characteristic $\mathrm{K} \alpha$ and $\mathrm{K} \beta$ lines of bromide were identified in blood (A), urine (B) and cerebrospinal fluid (C). The concentrations of bromide in blood, urine and cerebrospinal fluid were calculated as $108.1,41.2$ and $38.0 \mu \mathrm{g} / \mathrm{ml}$, respectively.

$S-K \alpha ; K \alpha$ line of sulfur: $K-K \alpha, \beta ; K \alpha$ and $K \beta$ lines of potassium: $F e-K \alpha, \beta ; K \alpha$ and $K \beta$ lines of iron: $\mathrm{Br}-\mathrm{K \alpha}$; $\mathrm{K} \alpha$ line of bromide: $\mathrm{Br}-\mathrm{K} \beta$; $\mathrm{K} \beta$ line of bromide. 